\title{
LEAN MANUFACTURING IN HEALTHCARE: A SYSTEMATIC REVIEW OF LITERATURE
}

\author{
Ana Claudia Dias ${ }^{1 *}$, Augusto Cunha Reis ${ }^{2}$, Renata Pereira Oliveira ${ }^{2}$, Úrsula Maruyama ${ }^{2}$, Paloma Martinez ${ }^{3}$ \\ 1. Universidade Federal Fluminense, 24210-253, Niterói-RJ, Brazil. \\ 2. Centro Federal de Educação Tecnológica Celso Suckow da Fonseca, 20271-110, Rio de Janeiro-RJ, Brasil. \\ 3. University of La Sabana, Chía, Cundinamarca, Colombia.
}

\author{
*missdias@gmail.com
}

\begin{abstract}
The healthcare environment aims at improving and quality in health management, with trends and practices in hospitals, institutions, clinics, laboratories and companies in this segment, with the purpose of bringing more comfort and better conditions in the care of patients. Faced with the difficulties of this area, it becomes increasingly important to reduce waste and improve processes. The goal of this paper is to carry out a systematic review of literature on the topic lean manufacturing in healthcare. The data were obtained from four online databases Web of Science, Science Direct, Emerald Insight and Scopus. Articles indexed in the last 10 years were selected (2006-2016). To select articles, an
\end{abstract}

advanced search was performed using the Boolean expression "E" that combined keywords for better specific results. Professionals working in the health segment will have the concepts and applied techniques, in addition to the work indexed in recent years, which will facilitate the research and development of the work, translating into increased efficiency and ultimately, improvement for the population. Despite the importance of the theme, there are few lean manufacturing jobs applied in the healthcare environment. This research can stimulate future studies due to its applicability for the improvement of health services.

KEYWORDS: lean manufacturing; healthcare; review of literature. 


\section{INTRODUCTION}

Lean manufacturing is a management philosophy focusing on waste reduction and focuses on delivering the highest quality product on time and at the lowest cost. The methodology appeared in the Toyota production system in 1950 and remains in the industry in several segments today as one of the most frequently used (YADAV; DESAI, 2016). A lean organization needs to understand the meaning of value for their specific customers and search for tools and techniques which help to eliminate waste, such as 5S, Kanban, and continuous improvement. The application of lean principles can be applied in industries, supply chains, education, Government and even in health area (MEYBODI, 2013).

Logical process used in industrial organizations. In other industries where profit maximization and shareholder wealth are primary motives, decisions are primarily driven by goal alignment for both managers and owners (LANGABEER, 2007). It involves individual care of patients, specific populations, and many professional groups within the same space. There is a need to assess traditional management approaches, divergent objectives and experience new structures to improve service delivered level (AUBRY et al., 2014).

As aging population increases, health services are important to Government evaluation and mitigate expenditure in healthcare (WAHAB; KEFELI, 2016). In underdeveloped countries or developing countries, such as Brazil, the economic crisis increases the difficulties faced by public hospitals with funding restrictions. Allied administrative mismanagement, lack decent and quality care to patients in the level of service provided (PEREIRA, 2014).

According to Wahab et al. (2016) health is one of the main drivers for country's development and economic growth, as it supports worker efficiency improvement and therefore his productivity. It is believed that progress on health indicators could, in the long term, increase countries GDP (gross domestic product).

In this context, best practices of lean healthcare can help improve health processes, because it is focused on patient, waste disposal, identification of bottlenecks, cost reduction and continuous improvement Abelhardi (2015) and Crema and Verbano (2015). The quest for increased quality in health services has become global and several recurring are the cases adopting lean tools in their hospital units (STENDER, 2016).

Academic literature regarding lean manufacturing in healthcare, lean manufacturing tools and techniques employed in the health environment was the foundation of this work. Furthermore, we intend to elaborate theoretical revision and analyze the results obtained throughout four online database platforms: Web of Science, Science Direct, Emerald Insight, and Scopus. In sum, professionals working in healthcare will have the tools and practices to improve processes and reduce waste.

\section{METHODOLOGY}

The methodology is given as the most important of research, because it defines means by which will be sought and obtained the answers to problems that occur in different areas of knowledge. In order to achieve this goal, one must select correctly the technique as well as the method adopted (LUDWIG, 2012). It also accounts for methods used to collect, process and analyze the data, to ensure the technical and theoretical accuracy to obtain applicable and real results (STENDER, 2016).

Methodological approach adopted in this research, first defined selection criteria and systematic theoretical search for later analyze and interpret the data. In this way, Li et al. (1995) classified literature reviews to summarize the state of the art in specific areas, distinguishing 
between revisions employing Delphi method, using meta-analysis, and those who employ content analysis.

Meta-analysis review evidence of multiple primary studies from the use of statistical instruments combined to increase objectivity and validity of the findings. Design must be very similar, if not identical. In meta-analysis approach, each study is synthesized, coded and entered in database. Subsequently, results are transformed into a common measure to calculate the overall dimension of the effect or the intervention measured (SHANKAR, 2006).

Content analysis allows researchers to select, filter and summarize volumes of data for your analysis. This technique facilitates the systematic and objective inference, which enables the identification of the relevant characteristics of a given subject, especially those isolated by several researchers (GAO, 1996). It differs from other review methods, because search possible biases in overcome each step, following a rigorous selection research method; relevance evaluation and validity; collection, synthesis and data interpretation (SHANKAR, 2006).

The chosen content analysis prepares its qualitative and exploratory-oriented character. It is important to define where the data will be collected. Rowley \& Slack (2004) indicate the database online as an important tool in the selection of articles from scientific journals. In addition, academics and professionals often use these bases to acquire knowledge and disseminating new results (NGAI et al., 2009). As usually studies tend not to be exhaustive, because other databases may contain additional relevant studies on the subject (REIS et al., 2013).

In this study, we decided to collect data exclusively from online databases: Science Direct, Emerald, Scopus and Web of Science. They were selected by providing a user-friendly interface and return a larger number of articles. However, it is known that other bases could contribute with relevant content to this study.

In addition, definition of keywords in elaboration research process is paramount to comply with the conditions required for theoretical basis and strengthen data discussed previously (STENDER, 2016). Inclusion criteria defined for papers selection during this work were indexes databases in the last ten years (2006 to 2016). It is important to mention that after paper classification, the same assessment had full content available on bases in English or Spanish, because they are universal languages.

By selecting articles, a detailed search was performed using Boolean expression "and" combining keywords for better results, as advocated in (ROWLEY; SLACK, 2004). All sciences were searched, because it was not objective restrict to a specific science research.

Therefore, the procedure of investigation included the term lean manufacturing in the title of the article and the term lean healthcare in all fields, separated by Boolean "and", because the interest was to analyze practices and lean manufacturing tools applied in healthcare environment. It is important to mention that healthcare is well known and disseminated by this work researcher, so we opted to use the full term and not only health.

The chosen theme, healthcare, is justified by the growing demand for health services, combined with financial limitations and the need to provide efficient services and excellence (PATEL et al., 2015). In addition, the health resources are scarce and often overloaded, which implies restrictions on the system (ZHANG et al., 2015).

Deslandes (1997) cites the importance of health, indicates it as relevant to public health. Once it enables a technical and social control of services, it also provides programs to society. In addition, healthcare service/user relationship can be an important index for assessing quality of care provided to population.

The effective management of health services, focus on processes, tends to bring benefits such as reducing delays in patient care, patient satisfaction and staff, in addition to improving service with lower costs of operation Patel (2015) and Zhang et al. (2015). Aguilar-Escobar et 
al. (2015) and Guimarães et al. (2013) mention that patient care is the result of a set of activities and that integration among sectors must occur synchronously.

\section{Results: Summary of the findings}

The obtained results in the selected databases, screened 49 articles indexed as shown in Table 1.

Table 1: search results of lean manufacturing in healthcare

\begin{tabular}{|l|l|l|l|l|l|l|l|l|l|l|l|l|}
\hline Year/Platform & 2006 & 2007 & 2008 & 2009 & 2010 & 2011 & 2012 & 2013 & 2014 & 2015 & 2016 & Total \\
\hline Web of Science & & & & & & & & 1 & 1 & 1 & 1 & 4 \\
\hline Emerald & & & & & & & & 1 & 4 & 2 & 2 & 9 \\
\hline Science Direct & & & & 1 & & & & & & 2 & & 3 \\
\hline Scopus & & & 2 & & 1 & 3 & 4 & 5 & 9 & 6 & 3 & 33 \\
\hline
\end{tabular}

Source: Authors

Science Direct is an online platform for access to scientific journals and e-books from Elsevier publisher. Advanced search on this basis indicated three articles. Emerald is an academic publisher of journals and books in several areas. Advanced search on this platform, contemplated nine items. Scopus is an abstract database and citations of its magazines include several publishers.

Advanced search on these databases indicated 33 articles. Web of Science asks signature by Thomson Reuters Scientific also provides many publishers search. On this basis, there were obtained four articles as a result. Timeline of indexed articles in databases is presented, in Chart 1, highlighting Scopus.

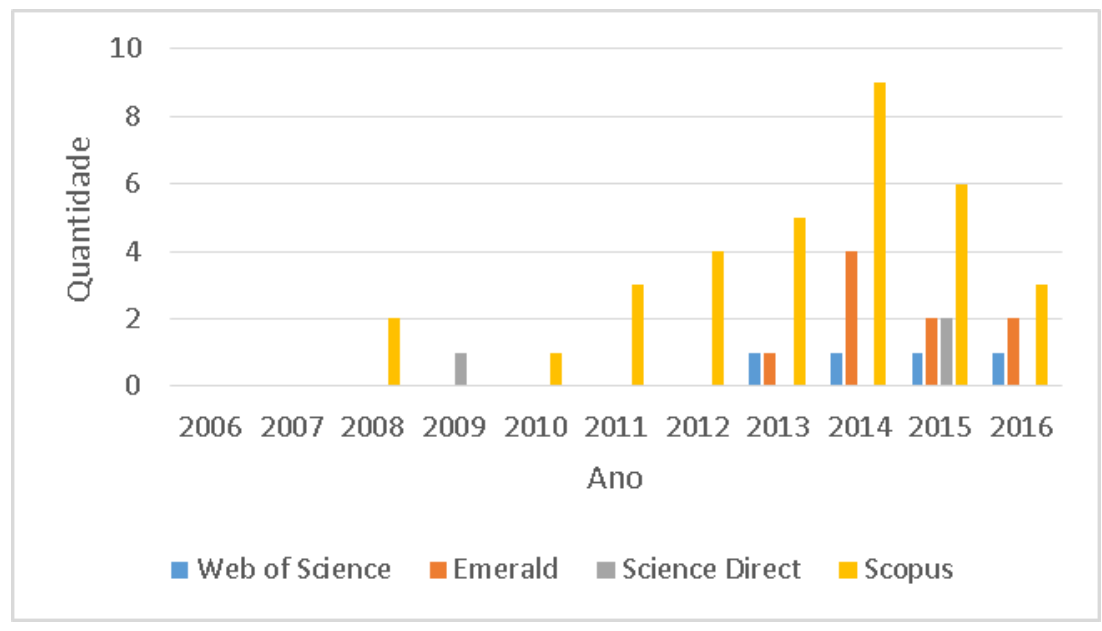

Chart 1- Papers Timeline indexed from lean manufacturing to healthcare.

Source: Authors

As Table 1 and Graph 1 analysis, 2014 was an important year to publications of lean manufacturing jobs applied in healthcare, having featured Emerald and Scopus databases. On Web of Science linear production started only in 2013. Science Direct was isolated showing in work publications indexed in this area in 2016. Emerald had a favorable number on returns of the works, but no publication from 2006 to 2012 on this topic. 
Scopus was a relevant database to academic production, which is justified by the fact it is a database which provides access to over 16,000 journal titles, over 1,200 free access magazines, more than 500 conference proceedings, more than 650 trade publications and more than 315 book series (BIBENG, 2016). In order to select items for systematic review of the literature, title and summary of all jobs were found in the title. In this step were discarded 19 articles by their content back to the healthcare environment: ten did not have your total available content and 9 were in duplicity. At last, 9 articles were kept due to their correspondence to the objectives, as Table 2 .

Table 2- Papers selected for analysis, as objective.

\begin{tabular}{|c|c|c|c|c|}
\hline Year & Number & Total & References & Source \\
\hline 2016 & 1 & 1 & Hasle et al. (2016) & $\begin{array}{l}\text { Human Factors And Ergonomics In } \\
\text { Manufacturing \& Service Industries }\end{array}$ \\
\hline \multirow[t]{4}{*}{2015} & 2 & 4 & Abdelhakim (2015) & $\begin{array}{l}\text { International Journal of Health Care } \\
\text { Quality Assurance }\end{array}$ \\
\hline & 3 & & Martínez et al. (2015) & Technological Information \\
\hline & 4 & & Kane et al. (2015) & Journal of Nursing Administration \\
\hline & 5 & & Savino et al. (2015) & $\begin{array}{l}\text { International Journal of Procurement } \\
\text { Management }\end{array}$ \\
\hline 2014 & 6 & 1 & Ismail et al. (2014) & $\begin{array}{l}\text { Arabian Journal for Science and } \\
\text { Engineering }\end{array}$ \\
\hline 2013 & 7 & 1 & Poksinska et al. (2013) & $\begin{array}{l}\text { Total Quality Management and Business } \\
\text { Excellence }\end{array}$ \\
\hline 2012 & 8 & 1 & Carter et al. (2012) & Academic Emergency Medicine \\
\hline 2009 & 9 & 1 & Riezebos, Klingenberg (2009) & Computers in Industry \\
\hline
\end{tabular}

Source: Authors.

Works were carried out worldwide: featured in European environment in general (3), specifically in Denmark, Italy and Sweden, in Asia (2) deployed by Malaysia and Saudi Arabia, American continent (2) United States and Colombia, in Africa a study in Ghana.

Indexes occurred in many sources such as information technology, nursing, medicine, business, engineering and management, among others. Journals shown in Table 2 are discussed below:

Human Factors And Ergonomics In Manufacturing \& Service Industries: covers issues relevant to design and manufacturing systems engineering, human resource management, social issues, health and safety organizations.

$\square$ International Journal of Health Care Quality Assurance: provides a forum for current thinking about theoretical and practical aspects of quality and management in healthcare and help to develop and continuously improvement in health organizations. The journal examines management and planning methods, discussing the introduction and maintenance of quality initiatives.

Technological Information: accept work in the Field of science, engineering and technology, research and have a relevant impact on development of Latin American countries. 
Journal of Nursing Administration: is designed for nurses, directors of nursing and nursing managers in hospitals, community health and ambulatory care environments.

$\square \quad$ International Journal of Procurement Management: development of supply resources, highlighting implications functions of managing procurements have on organizational productivity and competitiveness in the global market.

$\square$ Arabian Journal for Science and Engineering: provides opportunity to disseminate work in Civil Engineering, Chemistry, Electrical, Mechanical, Petroleum Engineering, Computer Science and Systems Engineering, in addition to Earth Sciences, Physics and Life Sciences.

$\square$ Total Quality Management and Business Excellence: it is intended to stimulate thought and research in all aspects of total quality management and continuous improvement.

$\square$ Academic Emergency Medicine: publishes works in academic medicine as clinical trials, diagnosis, and innovative therapies, clinical controversies, political or economic research, health services research, laboratory science, basic science studies, among others.

$\square$ Computers in Industry: covers new trends and options for the use of information and communication technologies (ICT) in industry like business processes, engineering, manufacturing, purchasing, physical distribution, production management and supply chain management.

Despite the few lean manufacturing jobs in healthcare environment, this theme can stimulate future studies due to its applicability and importance to the improvement of health services.

\section{DISCUSSION}

Lean manufacturing appeared in 1950 in automotive industry, Toyota production system, after World War II. Lean methodology had its first studies in health area in early 2000, which made it possible to confirm its application. The lean was dedicated with utmost strength in developed countries, such as England, United States, Australia, and also in emerging countries like India and Brazil (MARTINEZ et al., 2015).

Lean management in hospital can be compared to automotive industry. Although always existed the need for efficiency and quality in hospitals, the implementation of lean only occurred in the last millennium and more widespread only in recent years Hasle et al. (2016) and Riezebos \& Klingenberg (2009). Toyota's concepts application in health could lead to excellence in terms of efficiency and quality improvement. The interests in the application of such approach within health sector have increased significantly in recent years (SAVINO et al., 2016).

Many organizations are interested in adopting practices to improve its productivity, reduce costs, and increase competitive advantage. Lean production is no longer exclusively for the automotive industry and widely applied in other industrial sectors, including the service and health care (POKSINSKA et al., 2013). Despite health be regarded as a citizen's right, in practice this service provision is not adequate, which translates in failures and complaints from users (MARTINEZ et al., 2015).

Consequently, lean manufacturing can contribute positively to the development of health area, but it needs to be adapted to this environment. Reviews of the literature support the need for adaptation of lean tools to this reality (HASLE et al., 2016). On the other hand, lean metric can be valuable for health care and consequently for patient service (ABDELHADI, 2015). 
Lean manufacturing is a philosophy supported by several tools to improve quality, productivity, profitability and competitiveness for any corporation. Health professionals focus on improving customer service and reducing costs (ISMAIL et al., 2014).

Lean has become an integrated system covering highly related elements and extensive management practices, including just-in-time, quality systems, work teams, and others. The lean is much more than tools and techniques (because) it restores the organizational focus from the point of view of customer value and aligns all processes for this purpose (ABDELHADI, 2015).

Applying lean principles, Kanban techniques, Kaizen, 5S, among others, many times within information technology (IT) may develop some positive variants (RIEZEBOS; KLINGENBERG, 2009). Whence, hospitals are among the most complex organizations that exist: effective treatment requires individualized treatment plans, according to their needs; patients have multiple conditions in treatment. Another consideration to be made is the entry of critical patients is unpredictable.

However, application of lean in hospitals can improve outcome for patients, to extend experience in healthcare and can increase the profitability (HASLE et al., 2016). Management tools, such as visual control, daily meetings short and good communication are essential to encourage lean practices in health, since the processes in this area are not mature. The focus on managerial tasks must be in the processes for managing people. The main role of managers is now to motivate mentors to develop individuals and teams (POKSINSKA et al., 2013).

Lean projects have considerable results to reduce costs and improve processes. However, there are few cases of this type of project applied in hospital and when this occurs, the main objective is to improve the flow of patients through the reduction of the waiting time (HASLE et al., 2016).

Abdelhadi (2015) assessed management of resources in a hospital, in order to estimate the time of each patient in emergency beds and present the existence of bottlenecks in the process. It wasn't the goal investigating problem root cause, but to describe benchmarking practices enhancing performance. The author adopts lean Takt Time metric for both.

The German term takt time cycle means 'need'. The word was first introduced in the aerospace industry when it was used to synchronize production with the demand of customers to avoid overproduction. Means the time elapsed between units of output when the production rate is synchronized to meet customer demand. Is calculated dividing working time by customer demand time. Thus, takt time has the following benefits (ABDELHADI, 2015):

- Production flow stabilization: means that all stations wish to meet customers demand leading to consistency.

- Balance: when the job is equilibrated in a production line, all systems require the same amount of time to perform their tasks.

- Increased performance awareness: when takt time is displayed, production team can follow time and everyone can see where production is at every moment.

Hasle et al. (2016) carried out a case study in the department of cancer hospital in Denmark. He found that lean has been a strategic priority there since 2006. The unit collected a large number of improvements using kaizen, standardization of procedures and 5S. Kaizen was applied in two clinics of hospital pharmacy improving information flow to facilitate drug arrival for patients. The result was less medicine and less time and expenses wasted with issuance of urgent orders.

In addition, Kaizen activity meetings throughout hospital, resulting in more positive outcomes in logistics area. Procedures were standardized through short weekly meetings where collected ideas for improving processes. Ideas were then transformed into projects implemented or discarded. The $5 \mathrm{~S}$ was also used to rearrange layout, create more spaces in congested areas and order supply of materials, avoiding the shortages. 
Even Martínez et al. (2015) investigated emergency units to improve patient care time. It was made a summary of the average wait time for patients and applied lean manufacturing main tools. According to the authors, Value Stream Mapping (VSM) and spaghetti diagram allow viewing activities that do not generate value. As a result, it has been proposed that the screening should have a nursing assistant to help the patient in the hospital. In addition, it was appointed redistribution of physical space to match some processes in accordance with the current regulations. For example, one can cite separation of septic and aseptic procedures. Similarly, it was also indicated a decrease between the waiting room and doctors' offices, facilitating the flow of patients on site. The benefits of the work of Martínez et al. (2015) were:

- Decrease waste processes and remove those that do not add value to improve service provision to patients.

- Submit a case study of practical, feasible and cost effective through lean tools.

- Offer an application of lean in healthcare industry in Latin America, since this type of study is still incipient.

- Indicate that there is still ignorance of health professionals with lean practices to improve unit processes.

Likewise, Kane et al. (2015) suggest lean tools in Emergency Department to increase demand and improve customer service by reducing process waste. The result was a faster service, higher patient satisfaction and reducing the resources needed. The authors start using $5 \mathrm{~S}$ tool as a starting point to engage people in participating in improvements. It was subsequently applied the Kaizen to propose procedures for patient care more reliably and efficiently.

The next tool applied was Value Stream Mapping (VSM) identifying activities that could add value, those that do not add value, and then, those necessary versus unnecessary. Based on this analysis, it can develop a new stream, less waste and less down time for patients. Finally, developing and implementing a plan to achieve future state newly designed, engaging all professionals and proposing continuous improvement practices.

In the same line of research, Carter et al. (2012) describe application of lean manufacturing techniques to improve clinical operations in a hospital and reduce waiting time of patients. The goal was to improve identification of breastfeeding available and facilitate communication for patient transport. Lean project was conducted initially with kaizen to engage the team, describe the process steps, map value streams, root cause analysis and future planning. Then, Value Stream Mapping it was also used. Besides, lean has shown the adoption of its principles, with strong administrative support, leading organizations to be more adaptable, effective and efficient.

A differentiated analysis made by Poksinska et al. (2013) used Toyota's leadership in health down to four important steps:

Be committed to self-improvement: Toyota's leaders have a deep understanding of the work and the ability to develop and lead people, and are respected both for his expertise and leadership skills.

$\square$ Coaching and developing others: lean leaders must teach values and cultural norms to organization employees. Should also encourage, promote and facilitate organizational learning.

$\square$ Encourage Kaizen: leaders should encourage participation and improvement activities of daily basis.

$\square$ Create vision and align goals: develop long-term improvement goals. 
As lean improvement program was introduced, managers have become more visible in daily work and its primary task to support its employees. Formal and informal meetings with employees increased and became more important. Managers recognized that their role is to be facilitators and trainers and not simply controllers. Another major change was the increase of communication and flow of information. Instead of just informing by email, documents and information boards were transmitted in several short meetings. The standardized agenda and used meetings to receive feedback straight from employees. The objective was to develop an understanding of strategies and engage employees in improving quality, efficiency and safety (POKSINSKA et al., 2013).

Another point of view, was information systems (IT) application on lean production. Riezebos \& Klingenberg (2009) show that it can provide support for planners and officials decisions, through intelligent algorithms involved in adaptation systems control, as for example in the development of e-kanban. The authors argue that it can assist in increasing productivity and reducing waste through your applicability in lean in various industries and the environment.

Following to a production oriented environment, but in healthcare, Ismail et al. (2014) aimed to minimize wasteful practices, optimize workflow, eliminate unnecessary equipment and implement changes in a biopharmaceutical operation. In this study, Lean Six Sigma tool was applied to reduce the cycle time in one of production areas. Lean Six Sigma has as a priority the attainment of planned results and clear, involving quality_and costs. Functional Process Mapping (FPM) was used instead of VSM to improve communication and compression processes. FPM displays activities in sequential order and illustrates where each one is held. In addition, work analysis using maps helps to reduce cycle time, reduce defects, and increase productivity. The result of this study indicates that $95 \%$ of product's life cycle is spent in activities that do not add value and reduction in manufacturing time can improve process costs and maximize production.

Even in health, focusing on equipment used in a hospital, Savino et al. (2015) focuses on implementation of lean principles and concepts of Supply Chain Management (SCM), a company which provides and maintains power generators for hospitals, the requirements of on-time delivery and quality reliability must be particularly pleased. SCM aims to coordinate and integrate a number of activities related to improve efficiency, quality and customer service, generating sustainable competitive advantage in the market. The application of lean was used to improve processes and performance of health sector supply chain.

Before the presented studies, one can infer that in time, experience of lean will provide successful applications and deeper all hospital functions and processes (HASLE et al., 2016). For this reason, we need to train people in lean production to create a continuous improvement culture increasing service quality (ABDELHADI, 2015). In addition, it found difficulties to involve doctors in kaizen process since they regard as being administrative process and with little influence in your work and in patients (HASLE et al., 2016).

To make the initiative happens is important that organizational culture is adapted to it, as well as leadership. Once production lean in healthcare is a relatively new phenomenon, and cases applied are not yet mature, it is important to evaluate case studies of other areas to have a better perception of maturity and benefits of lean manufacturing (POKSINSKA et al., 2013). Hasle et al. (2016) indicates three possible explanations for the difficulty of applying lean healthcare:

Lean lack of maturity in healthcare.

Need to adapt Lean tools to simplify work with health

Complex nature of health and treatment processes. 
Despite of its difficulties, lean can be used as a tool to improve patient attention and through three basic steps (MARTINEZ et al., 2015).

- Document processes so it can present the ticket to patient in a health care unit until his departure.

- Identify steps for patient admission, discarding procedures that do not add value and indicating an ideal proposal.

- Propose a future value map with patient flow and improving customer service goal.

However, it is possible to realize various applications and objectives in the reviewed studies. Although applications of lean in healthcare are inceptive, their practices can contribute to the improvement of processes and patient care.

\section{CONCLUSION}

Healthcare issues still debatable, but application of lean manufacturing is growing. Eliminate waste in health care can be beneficial for achieving goals, as in a complex environment with budgetary constraint, lean tools and practices can help meet priorities, with quality and prepare for growth in demand.

There are a variety of journals that publish papers in this area, concluding the subject which is quite multidisciplinary. Several approaches can be made which makes it possible to publish in various periodicals.

It was found that Science Direct, Emerald and Web of Science have few works on this subject, but this last platform index. In addition, Scopus returned most of works indexed in different journals. Main tools used in research papers surveyed were: kanban, 5S, Kaizen and Value Stream Mapping, and the application of the tools in many areas such as: emergency hospital, clinical operations, information technology and even in medicine production.

All academic articles have limitations; this method does not run out the rule. This research used four online databases which does not cover the entire universe of available databases. Another limitation was the sample period which covered the last ten years. Limitations that described results were not exhaustive and cannot be generalized. For this reason, it is proposed for future work research on other databases, such as Scielo and Sucupira. Another recommendation is to expand the sample range changing terms used in the filters.

\section{REFERENCES}

ABDELHADI, A. Investigating emergency room service quality using lean manufacturing. International Journal of Health Care Quality Assurance, v. 28, n. 5, p.510-519, 2015.

AGUILAR-ESCOBAR, V.G., BOUQUE, S., GODINO-GALLEGO, N. Hospital kanban system implementation: Evaluating satisfaction of nursing personnel. Investigaciones Europeas de Dirección y Economía de la Empresa, v. 21, n. 3, p. 101-110, 2015.

AUBRY, M., RICHER, M-C., TREMBLAY, M.L. Governance performance in complex environment: The case of a major transformation in a university hospital. International Journal of Project Management, v. 32, p. 1333-1345, 2014.

BIBENG - Biblioteca da Escola de Engenharia da UFRGS - "Scopus - Tutorial”, 2014. Available at: http://www.ufrgs.br/bibeng/wp- content/uploads/2014/02/SCOPUS.pdf. Accessed on 23 June 2016.

CARTER, P.M., DESMOND, J.S., AKANBOBNAAB, C., OTENG, R.A., ROMINSKI, S.D., BARSAN, W.G., CUNNINGHAM, R.M. Optimizing clinical operations as part of a global emergency medicine initiative in Kumasi, 
Ghana: Application of lean manufacturing principals to low-resource health systems. Academic Emergency Medicine, v. 19, n.3, p. 338-347, 2012.

CREMA, M., VERBANO, C. How to combine lean and safety management in health care processes: A case from Spain. Safety Science, v. 79, p. 63-71, 2015.

DESLANDES, S.F. Concepções em pesquisa social: articulações com o campo da avaliação em serviços de saúde. Cad. Saúde Públ. Rio de Janeiro, v. 13, n. 1, p. 103-107, 1997.

GAO. Content analysis: a methodology for structuring and analyzing written material. United States General Accountability Office, 1996. Available at: http://archive.gao.gov/f0102/157490.pdf. Accessed on 18 June 2016).

GUIMARÃES, C.M., CARVALHO, J.C., MAIA, A. Vendor managed inventory (VMI): evidences from lean deployment in healthcare. Strategic Outsourcing: An International Journal, v. 6, n. 1, p. 8-24, 2013.

HASLE, P., NIELSEN, A.P., EDWARDS, K. Application of Lean Manufacturing in Hospitals the Need to Consider Maturity, Complexity, and the Value Concept. Human Industries, v. 4, p. 430- 442, 2016.

ISMAIL, A., GHANI, J.A., AB RAHMAN, M.N., MD DEROS, B., CHE HARON, C.H. Application of Lean Six Sigma Tools for Cycle Time Reduction in Manufacturing: Case Study in Biopharmaceutical Industry. Arabian Journal for Science and Engineering, v. 39, p. 1449-1463, 2014.

KANE, M., CHUI, K., RIMICCI, J., CALLAGY, P., HEREFORD, J., SHEN, S., NORRIS, R., PICKHAM, D. Lean manufacturing improves emergency department throughput and patient satisfaction. Journal of Nursing Administration, v. 45, p. 429-434, 2015.

LANGABEER, J,R. Health care operations management: a quantitative approach to business and logistic. Jones and Bartlett Publishers, US. ISBN-13:978-07637-5051-0, 2007.

LI, T.S., CAVUSGIL, T.A. Classification and assessment of research streams in International Marketing. International Business Review, v. 4, n. 3, p. 251-277, 1995.

LUDWIG, A. C. W. Fundamentos e prática de metodologia científica. 2. ed. Petrópolis: Vozes. p. 124, 2012.

MARTINEZ, P., MARTINEZ, J., NUNO, P., CAVAZOS, J. Mejora en el Tiempo de Atención al Paciente en una Unidad de Urgencias Mediante la Aplicación de Manufactura Esbelta,.Source of the Document Informacion Tecnologica, v. 26, p. 187-198, 2015.

MEYBODI, M. Z. The links between lean manufacturing practices and concurrent engineering method of new product development. Benchmarking: An International Journal, v. 20, n. 3, p. 362-376, 2013.

NGAI, E. W. T., XIU, L.; CHAUD, D. C .K. Application of data mining techniques in customer relationship management: A literature review and classification. Expert Systems with Applications, v. 36, p. 2592-2602, 2009.

PATEL, K.K., CUMMINGS, S., SELliN, J., SCOTT, L. and EL-SERAG, H.B. Applying Lean Design Principles to a Gastrointestinal Endoscopy Program for Uninsured Patients Improves Health Care Utilization. Clinical Gastroenterology and Hepatology, v. 13, n. 9, p. 1556-1559, 2015.

PEREIRA, L.C.B. Uma reforma gerencial da administração pública no Brasil. Revista do Serviço Público. v. 49, n. 1, p. 5-42, 2014.

POKSINSKA, B., SWARTLING, D., DROTZ, E. The daily work of Lean leaders - lessons from manufacturing and healthcare. Total Quality Management and Business Excellence, v. 24, n. 8, p. 886-898, 2013.

REIS, A.C., SCAVARDA, L.F. and PANCIERI, B.M. Product variety management: A synthesis of existing research. African Journal of Business Management. v. 7, n. 1, p. 39-55, 2013.

RIEZEBOS, J. and KLINGENBERG, W. Advancing lean manufacturing, the role of IT. Computers in Industry. v. 60, p. 235-236, 2009.

ROWLEY, J., SLACK, F. Conducting a literature review, Management Research News, v. 27, n. 6, p. 31-39, 2004.

SAVINO, M.M., MAZZA, A. and MARCHETTI, B. Lean manufacturing within critical healthcare supply chain: An exploratory study through value chain simulation. International Journal of Procurement Management, v. 8, n. 1/2, p. 3-24, 2015.

SHANKAR, V. Proactive and Reactive Product Line Strategies: Asymmetries Between Market Leaders and Followers. Management Science, v. 52, n. 2, p. 276-292, 2006. 
STENDER, G.H.C. Lean Health Care: Modelo de Implantação da Ferramenta Kanban a um Almoxarifado de um Hospital Federal no Rio De Janeiro, Dissertation master - Graduate Program in Production Engineering and Systems, CEFET/RJ. Rio de Janeiro, 2016.

YADAV, G., DESAI, T.N. Lean Six Sigma: a categorized review of the literature. International Journal of Lean Six Sigma, v. 7, n. 1, 2016.

WAHAB, A.A.O.A., KEFELI, Z. Projecting a Long Term Expenditure Growth in Healthcare Service: A Literature Review. Procedia Economics and Finance, v. 37, p. 152-157, 2016.

ZHANG, L., RUNZHEIMER, K., BONIFER, E., KEULERS, A., PIECHOWIAK, E., MAHNKEN, A. Improving Efficiency of Interventional Service by Lean Six Sigma. Journal of the American College of Radiology, v. 12, n. 11, p. $1200-1203,2015$.

This work is licensed under a Creative Commons Attribution 4.0 International License. 